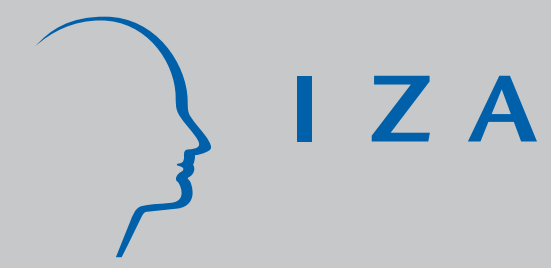

IZA DP No. 204

Labor Market Interactions Between Legal and Illegal Immigrants

Gil S. Epstein

October 2000 


\title{
Labor Market Interactions Between Legal and IIlegal Immigrants
}

\author{
Gil S. Epstein \\ Bar-Ilan University, Israel, CEPR, London and IZA, Bonn
}

Discussion Paper No. 204

October 2000

\author{
IZA \\ P.O. Box 7240 \\ D-53072 Bonn \\ Germany \\ Tel.: +49-228-3894-0 \\ Fax: +49-228-3894-210 \\ Email: iza@iza.org
}

This Discussion Paper is issued within the framework of IZA's research area Mobility and Flexibility of Labor Markets. Any opinions expressed here are those of the author(s) and not those of the institute. Research disseminated by IZA may include views on policy, but the institute itself takes no institutional policy positions.

The Institute for the Study of Labor (IZA) in Bonn is a local and virtual international research center and a place of communication between science, politics and business. IZA is an independent, nonprofit limited liability company (Gesellschaft mit beschränkter Haftung) supported by the Deutsche Post AG. The center is associated with the University of Bonn and offers a stimulating research environment through its research networks, research support, and visitors and doctoral programs. IZA engages in (i) original and internationally competitive research in all fields of labor economics, (ii) development of policy concepts, and (iii) dissemination of research results and concepts to the interested public. The current research program deals with (1) mobility and flexibility of labor markets, (2) internationalization of labor markets and European integration, (3) the welfare state and labor markets, (4) labor markets in transition, (5) the future of work, (6) project evaluation and (7) general labor economics.

IZA Discussion Papers often represent preliminary work and are circulated to encourage discussion. Citation of such a paper should account for its provisional character. 
IZA Discussion Paper No. 204

October 2000

\section{ABSTRACT \\ Labor Market Interactions Between Legal and Illegal Immigrants*}

This paper looks at the situation of legal immigrants who employ illegal immigrants to provide them with various services. This enables the legal immigrants to allocate more time to other work, thereby increasing their earnings. Illegal immigrants employed by legal immigrants may specialize in certain professions and may themselves employ other illegal immigrants. An economy is evolving whose sole purpose is the provision of services by illegal immigrants for legal immigrants.

JEL-Classification: F22, K42, P16

Keywords: Illegal migration, legal migration, guest workers

Gil S. Epstein

Department of Economics

Bar-Ilan University

52900 Ramat-Gan

Israel

Tel: +972-3-531-8937

Fax: +972-3-535-3180

Email: epsteig@mail.biu.ac.il

\footnotetext{
* An earlier version of this paper was presented at the weekly seminar at IZA, Bonn and at the CEPR and ESRI conference on Marginal Labour Markets in Metropolitan Areas, Dublin, October 1999. I am grateful to the participants for their helpful comments. In particular I am grateful to Alan Barrett, Thomas Bauer, Barry Chiswick, Don DeVoretz, Christian Dustmann, Peter Fredriksson, Ira Gang, Edward Glaeser, Jorgen Hansen, Magnus Lofstrom, Kostas Mavromaras, and Klaus F. Zimmermann. I am also grateful to Avraham Lioui, for helpful and fruitful discussions and comments.
} 


\section{Introduction}

Legal temporary workers are granted entry to host countries to work in specific assigned jobs, to which they are limited by law. However, since such workers aim to maximize earnings during the period spent in the host country, there is an incentive for them also to take on jobs which are not allocated to them legally (hereinafter, illegal jobs). Illegal workers entering host countries (Borjas, 1994 and Ethier, 1986) cannot find jobs as easily as legal workers and tend to use the existing networks generated by the local migrants (legal and illegal) to find jobs.

In this process, both legal and illegal migrants gain specific human capital, thereby increasing their incomes over time. These include: on-the-job training, learning the language, etc. Legal immigrants may work in both legal and illegal jobs; therefore their reservation wage is higher than that of illegal migrants, who are restricted to illegal jobs. The increase in specific human capital, and, hence income, for both legal and illegal immigrants enables them to employ newly arrived illegal immigrants with low specific human capital looking for other sources of income. Naturally, illegal immigrants turn to the local network for help.

Our goal in this paper is to explore the labor market interactions between legal and illegal immigrants. We describe the stylized relationships within the immigrant community. Illegal immigrants may substitute for the legal immigrants to some extent at home, specializing in certain fields or professions. Such assistance enables the immigrants to devote more time to increasing their earnings. Immigrants generally prefer to employ migrants from their own country as they come from a similar environment, culture, and language, enhancing network externalities (Marks 1989, Church and King 1993, Carrington, Detragiache, Vishwanath 1996 and Chiswick and Miller 1996). Therefore, a sub-economy is emerging whose sole purpose is to provide services for migrants. ${ }^{1}$

Various public policies directed at dealing with these phenomena are examined. We consider the implications of: $a$. taxing legal migrants' earnings, $b$. changing the time period a legal immigrant/temporary worker is allowed to stay in the host country, $c$. requiring renewal of permits to stay in the country at regular intervals, $d$. imposing a penalty on local employers caught illegally employing migrants, and $e$.

${ }^{1}$ Much of this economy is illegal. In Malaysia and Israel temporary migrant workers, both legal and illegal employ illegal migrants. 
forced savings, whereby migrants are compelled to save part of their legal earnings, which they would lose if deported.

This paper is divided as follows: Section 2.1 describes the basic model considering the legal migrants' allocation of time spent at illegal jobs. Section 2.2 considers the effect wealth accumulation on the legal migrants' decisions. Section 2.3 considers the effect of changes in the migrants' human capital over time on the allocation of time. In section 3, we discuss the opportunities for legal migrants to employ illegal migrants. Section 4 focuses on the employment of illegal immigrants by other illegal immigrants. Finally, Section 5 analyzes the implications of five different public policies directed at the evolving sub-economy.

\section{The Model}

\subsection{The Basic Model}

A legal immigrant works at his/her legal job. At the end of the day (week, etc.), after completing his/her obligations to the legal employer, he/she may decide to devote his/her time working at an illegal job to increase his/her earnings/utility. The utility the immigrant receives from leisure after finishing his/her obligations to the legal employer is normalized to zero ${ }^{2}$. If an immigrant is caught working in an illegal job, he/she will be deported. To simplify, we assume that the alternative earnings in the home country is fixed at zero. (Alternatively: the immigrant maximizes the increase in earnings relative to the wages he/she would have received at home). Moreover, at this point we assume that the immigrants' division of time between work and the home is fixed. The immigrant's objective is to maximize his/her expected utility (earnings) by determining the proportion of time spent on the illegal market, $\alpha(0 \leq \alpha \leq 1)$. The immigrant's working permit is for a period of time $T .^{3}$

The immigrant works on the legal market at a given job that has a fixed wage $w^{L}$. Hours spent on the legal jobs are also fixed and normalized to 1 so that $w^{L}$ represents earnings from legal employment. Alternatively we could look at the time spent at legal jobs as endogenous. Here we have decided no to take this approached

${ }^{2}$ This assumption simplifies the calculations. The main results still hold under the case where there is a utility from leisure.

${ }^{3}$ In order to consider a permanent legal migrant one must set $T \rightarrow \infty$. 
for two reasons: $a$. it seems more realistic that when a legal immigrants enters the country he workers at an assigned job for which he/she received a permit and $b$. it would complicate the notation while the results would stay the same.

The wages for the illegal jobs are fixed at $w^{I}$ per job. Assuming that effort gives decreasing returns: $I(\alpha)$, the earnings from illegal work, increase with $\alpha$ with a decreasing marginal. ${ }^{4}$ The probability of being caught working on the illegal market, $P\left(\right.$.), is a positive function of the proportion of time spent working there. ${ }^{5}$

A legal immigrant caught working in an illegal job is deported and loses out in two ways. He forfeits future earnings as well as some of his wealth and social ties.

Immigrants aim to maximize their expected earnings/utility (earnings). Towards this end, they have to decide on the proportion of time to spend on the illegal market. The general problem can be represented as follows ${ }^{6}$ :

${ }^{4}$ An alternative assumption would be that $I(\alpha)=\alpha w^{I}$. In this case the result would still hold under more restricted assumptions for the probability of being caught.

5 The allocation of time for the different tasks has been analyzed in the literature starting with Becker (1965). There is a great deal of literature on the allocation of time and resources between legal and illegal activities (Block and Heineke, 1975 and Ehrlich, 1973). There are two main differences between our approach and the approach taken in the literature. First, a criminal who is caught may return to commit more illegal activities after serving his time. In our story, when caught the immigrant is deported. Second, in the literature the criminal has an infinite horizon while in our case there is a given time-permit.

${ }^{6}$ In the case where there is utility from leisure then the expected utility is:

$$
E\left(U_{t-1}\right)=(1-P(\alpha))\left(I(\alpha)+u(1-\alpha)+w^{L}+\frac{1}{1+r} E\left(U_{t}^{*}\right)\right) \text { with } u^{\prime}>0 \text { and } u^{\prime \prime}<0 \text {. }
$$

In the case where the time spent in the legal market is endogenous, $\mathrm{L}$ is the legal earnings: $E\left(U_{t-1}\right)=(1-P(\alpha))\left(I(\alpha)+L(1-\alpha)+\frac{1}{1+r} E\left(U_{t}^{*}\right)\right)$ with $L^{\prime}>0$ and $L^{\prime \prime}<0$. 


$$
E\left(U_{t-1}\right)=(1-P(\alpha))\left(I(\alpha)+w^{L}+k E\left(U_{t}^{*}\right)\right) \quad \forall 1 \leq t<T \text { and } 0 \leq \alpha \leq 1
$$

and

$$
E\left(U_{T}\right)=(1-P(\alpha))\left(I(\alpha)+w^{L}\right)
$$

where $k=1 /(1+r)$ is the discount factor, $r$ represents the immigrant's time preference and $E\left(U_{t}^{*}\right)$ is the expected earnings at period $t$, given the optimal levels of $\alpha$ (from time $t$ to $T$ ). With probability $P(\alpha)$ the migrant is caught and receives an expected earnings of zero. Starting at time $T$ :

Time Period T: The migrant's expected earnings in time period $T$ are given by,

$$
E\left(U_{T}\right)=(1-P(\alpha))\left(I(\alpha)+w^{L}\right)
$$

The first-order condition is given by,

$$
\frac{\partial E\left(U_{T}\right)}{\partial \alpha}=-\frac{\partial P(\alpha)}{\partial \alpha}\left(I(\alpha)+w^{L}\right)+(1-P(\alpha)) \frac{\partial I(\alpha)}{\partial \alpha}=0
$$

Assuming the second-order condition is satisfied: ${ }^{7}$

$$
\frac{\partial^{2} E\left(U_{T}\right)}{\partial^{2} \alpha}=-P^{\prime \prime}(\alpha)\left(I(\alpha)+w^{L}\right)-2 P^{\prime}(\alpha) I^{\prime}(\alpha)+(1-P(\alpha)) I^{\prime \prime}(\alpha)<0
$$

where $P^{\prime}(\alpha)=\frac{\partial P(\alpha)}{\partial \alpha} ; P^{\prime \prime}(\alpha)=\frac{\partial^{2} P(\alpha)}{\partial \alpha^{2}} ; I^{\prime}(\alpha)=\frac{\partial I(\alpha)}{\partial \alpha}$ and $I^{\prime \prime}(\alpha)=\frac{\partial^{2} I(\alpha)}{\partial \alpha^{2}}$.

Rewriting (2), gives:

$$
I^{\prime}(\alpha)=\left[P^{\prime}(\alpha) /(1-P(\alpha))\right]\left(I(\alpha)+w^{L}\right)
$$

The $\alpha$ which satisfies (4) is denoted by $\alpha_{T}^{*}$. Given $\alpha_{T}^{*}$ we obtain:

${ }^{7}$ A sufficient, but not necessary, condition for (3) is that the probability of being caught has a positive second derivative. (3) holds in the case where there are constant returns for effort on the illegal market. 


$$
E\left(U_{T}^{*}\right)=\left(1-P\left(\alpha_{T}^{*}\right)\right)\left(I\left(\alpha_{T}^{*}\right)+w^{L}\right)
$$

Time Period T-1: The migrant's expected earnings in $T-1$ are given by

$$
E\left(U_{T-1}\right)=(1-P(\alpha))\left(I(\alpha)+w^{L}+k E\left(U_{T}^{*}\right)\right)
$$

The first-order condition for (6) is satisfied if:

$$
I^{\prime}(\alpha)=\left[P^{\prime}(\alpha) /(1-P(\alpha))\right]\left(I(\alpha)+w^{L}+k E\left(U_{T}^{*}\right)\right)
$$

For a given $\alpha$, the RHS of (7) is greater than that of (4) therefore $\alpha_{T-1}^{*}<\alpha_{T}^{*}$. This may be generalized in the following proposition:

Proposition 1:Over time, the proportion of time spent on the illegal market increases.

Proof: see Appendix.

According to this proposition, the longer immigrants are in the host country, the more time they spend working in illegal jobs (see Fig. 1) since the cost of being caught on the illegal market decreases with time. This assumption may be relaxed by introducing an additional penalty if caught (see below).

\subsection{A Model Including Accumulation of Wealth}

We now assume that immigrants accumulate wealth, which is lost if they are caught working on the illegal market. Since immigrants caught on the illegal market are expelled from the country, they cannot liquidate all their capital overnight, which, therefore, constitutes a loss. Moreover, there is also a social cost, i.e. losing friends made over the years.

Denote the amount of wealth accumulated over $t$ by $K_{t}($.$) . K_{t}($.) is function of the legal immigrants' total amount of earnings until $t: K_{t}\left(\sum_{i=1}^{t-1}(1+r)^{t-i}\left(I\left(\alpha_{t}\right)+w^{L}\right)\right)$. Denote the wealth accumulation by $K(t)$. Most of the temporary workers' earnings are sent home and, therefore, would not be lost if deported. We assume that the legal 
immigrants' major source of income is from the legal jobs and since this is fixed, the accumulation of wealth is independent of the proportion of time spent in illegal jobs.

Time Period T: The migrant's expected earnings during $T$ are given by:

$$
E\left(U_{T}\right)=(1-P(\alpha))\left(I(\alpha)+w^{L}\right)-P(\alpha) K(T)
$$

The first-order condition is satisfied if:

$$
I^{\prime}(\alpha)=\left[P^{\prime}(\alpha) /(1-P(\alpha))\right]\left(I(\alpha)+w^{L}+K(T)\right)
$$

Denote the $\alpha$ that satisfies (9) by $\alpha_{K, T}^{*}$. We now compare the proportion of time spent on the illegal market with or without the accumulation of capital. Technically, the RHS of (9) should be compared with that of (4), for a given $\alpha$ :

$$
\begin{aligned}
\operatorname{RHS}(9)=\left[P^{\prime}(\alpha) /(1-P(\alpha))\right]( & \left.I(\alpha)+w^{L}+K(T)\right) \\
& >\left[P^{\prime}(\alpha) /(1-P(\alpha))\right]\left(I(\alpha)+w^{L}\right)=R H S(4)
\end{aligned}
$$

The accumulation of capital increases the cost of working on the illegal market, and, therefore, immigrants wishing to maximize their expected earnings spend less time working in illegal jobs $\left(\alpha_{K, T}^{*}<\alpha_{T}^{*}\right)$. This may be generalized: The proportion of time spent on the illegal market is higher in the model without than in the one with the accumulation of wealth. As a result of preparations to leave for home, during the time period $t_{l}$, the total level of wealth accumulated lost if immigrants are caught is reduced

Proposition 2: If the accumulation of wealth is independent of the proportion of time spent in illegal jobs, the curve of the relationship between the time spent in the host country and the proportion of time spent on the illegal market is U-shaped.

Proof: see Appendix

With time, immigrants spend less time on the illegal market since the cost of being caught increases. In the period prior to their return, they start "selling" assets, 
such as home equipment, among others. Therefore, the cost of being caught decreases, increasing the incentive to spend more time in the illegal market (see Fig. 2.).

\subsection{Changes in Human Capital}

We consider the effect of changes in human capital over time on the time spent on the illegal market. The increase in human capital over time is due to on-the-job training, learning the language, etc. We assume the increase in human capital is higher on the legal than on the illegal market. While learning by practice takes place on both the legal and illegal markets, the legal immigrant has more freedom and choice of work: $\frac{\partial I_{t}(\alpha)}{\partial t}>0, \frac{\partial w_{t}{ }^{L}}{\partial t}>0$ and $\frac{\partial I_{t}(a)}{\partial t}<\frac{\partial w_{t}{ }^{L}}{\partial t}$. To simplify, we return to the basic model. During $T$, the first-order condition is (similarly to (4)):

$$
I^{\prime}{ }_{T}(\alpha)=\left[P^{\prime}(\alpha) /(1-P(\alpha))\right]\left(I_{T}(\alpha)+w_{T}{ }^{L}\right)
$$

At $T-1$, the first-order condition is (similarly to (7)):

$$
I_{T-1}^{\prime}(\alpha)=\left[P^{\prime}(\alpha) /(1-P(\alpha))\right]\left(I_{T-1}(\alpha)+w_{T-1}{ }^{L}+\frac{1}{1+r} E\left(U_{T}{ }^{*}\right)\right)
$$

Given $\alpha$ the RHS of (12) is greater than that of (11): immigrants spend more time on the legal market in $T-1$ than in $T$. The proportion of time spent on the legal market decreases with length of stay in the host country. However, it is higher if the human capital level changes over time, since the cost of being caught increases with time:

Proposition 3: If the immigrants' human capital increases over time, they spend more time on the legal market.

\section{Employment of illegal immigrants by legal immigrants}

Taking care of home and family, such as cleaning, cooking, and educating children, etc., is time-consuming. In the pervious sections it has been implicitly assumed that the immigrants' division of time between work and home is fixed. In this section, we consider the consequences of immigrants deciding to employ other immigrants to do 
some of the chores. ${ }^{8}$ This would allow immigrants to devote more time to work, thereby increasing their earnings.

Legal immigrants may work at jobs open to illegal workers as well as at those that are closed to them. Thus, illegal immigrants' wages are lower than the legal immigrants. Moreover, legal immigrants have more opportunities, freedom and choice than illegal immigrants, and, therefore, their reservation wages are higher.

The legal immigrant, who works on both the legal and illegal markets, has a higher rate of increase of human capital than the illegal migrant. Moreover, a legal immigrant who has been in the country for some time earns more than an illegal immigrant recently arrived. To simplify, it is assumed that an immigrant who does not employ an illegal immigrant, devotes one unit of time to work and $\bar{\delta}$ units of time to housework. ${ }^{9}$

Let $\delta,(\delta<\bar{\delta})$ denote the maximum time for which the illegal immigrant can replace the legal immigrant at home. The proportion of time in which the illegal worker replaces the legal worker is denoted by $\beta$, such that $0 \leq \beta \leq \delta<\bar{\delta}$. The time saved by the legal immigrant can be spent generating earnings. Denote by $v_{t}(\beta)$ the wage paid at time $t$, per unit of time, by the legal immigrant to the illegal immigrant:

$$
\frac{\partial v_{t}(\beta)}{\partial \beta}>0, \quad \frac{\partial^{2} v_{t}(\beta)}{\partial \beta^{2}}<0, v_{t}(0)=0 \text { and } \frac{\partial v_{t}(\beta)}{\partial t} \geq 0
$$

The first condition simply states that the longer the worker is employed, the more the employer has to pay. The second condition states that there are diminishing returns to work. The third condition states that there is no cost involved if a worker is not taken on. The fourth condition states that the illegal immigrant's earnings may increase over time due to a rise in human capital.

${ }^{8}$ Legal immigrants may employ illegal immigrants in order to hire them out to local employers. Considering this situation would enhance the results.

${ }^{9}$ Endogenousing the time spent at home would change the absolute results but it would not change the main findings of our analysis. 
The illegal immigrant works for the legal immigrant for $\beta$ units of time, freeing the legal immigrant to work at illegal jobs during this time:. The legal immigrant's expected earnings are given by:

$$
\begin{gathered}
E\left(U_{t-1}\right)=(1-P(\alpha))\left(I_{t-1}(\alpha+\beta)+w_{t-1}{ }^{L}+k E\left(U_{t}{ }^{*}\right)-v_{t-1}(\beta)\right) \quad \forall 0 \leq t<T \\
\text { and } \\
E\left(U_{T}\right)=(1-P(\alpha))\left(I_{T}(\alpha)+w_{T}{ }^{L}-v_{T}(\beta)\right)
\end{gathered}
$$

where $0 \leq \beta \leq \delta$.

The legal immigrant makes two related decisions: determining the time the illegal immigrant spends working for him/her, $\beta$, and the proportion of time spent on the illegal market, $\alpha+\beta$. $\alpha$, of course, will be a function $\beta$. A legal immigrant employs an illegal immigrant if, and only if, his/her earnings would thereby be expected to increase. At time $t(0 \leq t<T)$, denote the time spent on the illegal market and the employment time of the illegal immigrant by $\alpha_{t}^{*}$ and $\beta_{t}^{*}$ respectively. The immigrant's expected earnings at time $t-1(0 \leq t<T)$ :

$$
E\left(U^{*}{ }_{t-1}\right)=(1-P(\alpha))\left(I_{t-1}\left(\alpha^{*}{ }_{t-1}+\beta^{*}{ }_{t-1}\right)+w_{t-1}{ }^{L}+k E\left(U_{t}^{*}\right)-v_{t-1}\left(\beta^{*}{ }_{t-1}\right)\right)
$$

However, if legal immigrant does not employ the illegal immigrant, at time $t$ $(0 \leq t<T)$ he/she will spend $\alpha_{t}^{* *}$ units of time on the illegal market with $\beta_{t}^{* *}=0$. In this case, the legal immigrant's expected earnings at time $t-1$ would be:

$$
E\left(U_{t-1}^{* *}\right)=(1-P(\alpha))\left(I_{t-1}\left(\alpha^{*}{ }_{t-1}\right)+w_{t-1}{ }^{L}+k E\left(U_{t}^{*}\right)\right)
$$

Note that the employer might not employ illegal immigrants during a time period $t-1$, but would do so during $t$.

Lemma 1: Legal immigrants employing illegal immigrants during time period $t-1=\underline{t},\left(E\left(U_{t-1}^{* *}\right)<E\left(U_{t-1}^{*}\right)\right)$ would employ them for the entire duration of their stay $T \geq t-1>\underline{t}$. 
Proof: see appendix.

The lemma states that if, at one point in time, it was worthwhile employing an illegal worker, it would continue to be so from then onwards.

Proposition 4: The probability of legal immigrants employing illegal immigrants increases with time. Moreover, the proportion of time illegal immigrants spend working for legal immigrant increases over time.

According to proposition 4, the longer legal immigrants stay in the host country, the higher the probability they would employ illegal immigrants, and the greater the proportion of time spent in such employment. ${ }^{10}$

\section{Employment of Illegal Immigrants by Illegal Immigrants}

As well as working for legal immigrants, illegal immigrants spend time taking care of their own family. Illegal immigrants have to decide how to divide their time between work and the family. The illegal immigrants' human capital increases over time. Therefore, it may well be that, after a certain period of time they decide to employ other immigrants to help them at home with cleaning and looking after the children, among other tasks. As mentioned in the introduction, immigrants generally prefer to employ migrants from with similar social and cultural background, thereby enhancing network externalities. Taking such a step allows immigrants to increase their working time for other legal or illegal immigrants and/or local employers.

At time $z$, the expected earnings of an illegal immigrant working for a legal immigrant are given by:

$$
E\left(V_{z}\right)=(1-q(\gamma))\left(v_{z}(\gamma)+k E\left(V_{z+1}^{*}\right)\right)
$$

where $\gamma$ is the proportion of time spent working on the illegal market and $E\left(V_{z+1}{ }^{*}\right)$ are the immigrant's expected earnings for the time period $z+1$, given that the proportion of time he/she chooses to devote to work is optimal. The term $q(\gamma)$ is the illegal immigrant's probability of being caught and thrown out of the host country.

${ }^{10}$ This fact is going to be a key issue determining public policy. 
While both legal and illegal immigrants face similar problems, there are several differences: (1) Illegal immigrants cannot work in legal jobs. (2) Whereas, in both cases, the probability of being apprehended is a direct function of the time spent working on the illegal market, legal immigrants only face being caught during the time they spend working on the illegal market, while the illegal immigrant may be apprehended at all times (at work or watching TV at home). This may be expressed as follows:

$$
\frac{\partial q(a)}{\partial a}>0, \quad q(0)>0 \quad \text { and } q(a)>P(a)
$$

Illegal immigrants may employ other illegal immigrants, for example, sending their children to a "school" run by an illegal-immigrant teacher who, of course, may be teaching more than one child simultaneously or participating in religious services run by a minister who is an illegal immigrant. Such measures would give the immigrant more time to devote to working and generating income.

Similarly to (15), the immigrant's situation may be expressed as follows:

$$
E\left(V_{z}\right)=(1-q(\gamma+\lambda))\left(I_{z}(\gamma+\lambda)+k E\left(U_{z}^{*}\right)-v_{v}(\lambda)\right)
$$

where $\lambda$ denotes the time period over which the immigrant employs a new immigrant who previously worked in the home country for a period of time $v$.

Illegal immigrants employ immigrants only if their earnings are high enough. Since the immigrant's human capital increases over time, this leads to the following:

Proposition 5: The probability of illegal immigrants employing other illegal immigrants increases with time. Moreover, the proportion of time illegal immigrant allocate to working for other illegal immigrants also increases over time.

Summarizing propositions 4 and 5, with time, more and more illegal immigrants work for legal and illegal immigrants in the host country. For example, legal and illegal immigrants employ illegal teachers. The illegal teachers employ illegal immigrants to do their housework etc. Thus, $A$ sub-economy of illegal immigrants, mainly serving immigrants from the same home country, develops in the host country. This, of course, does not take into consideration the option that, after time $T$, the legal 
immigrant may remain in the host country as an illegal immigrant. ${ }^{11}$ Thus, allowing legal immigrants to enter the host country generates jobs for illegal immigrants.

\section{Policy Implications}

A sub-economy of migrants is emerging whose sole purpose is the provision services by illegal immigrants for legal and illegal immigrants. This may not be in the interest of the host country. In this section we focuses on the demand for immigrants (assuming there is an initial pool of immigrants) and consider the implications of various public policy strategies that may affect the evolving new sub-economy. ${ }^{12}$ These include: taxing legal immigrants' earnings; changing the time period a legal immigrant is allowed to stay in the host country; a regular renewal permit restriction; imposing a penalties on local employers caught illegal immigrant; and forced savings.

\subsection{Earnings Tax}

Let $\mu$. denote the tax rate. Assume the tax burden falls on the immigrant, i.e., the labor supply is assumed to be completely inelastic (if this is not so, the tax burden would be lower, however the analytical treatment would be similar).

The immigrant's expected earnings at time $t-1$ are given by

$$
E\left(U_{t-1}\right)=(1-P(\alpha))\left(I(\alpha)+(1-\mu) w^{L}+k E\left(U_{t}^{*}\right)\right)
$$

The first-order condition is satisfied if:

$$
I^{\prime}(\alpha)=\left[P^{\prime}(\alpha) /(1-P(\alpha))\right]\left(I(\alpha)+(1-\mu) w^{L}+k E\left(U_{t}^{*}\right)\right)
$$

The RHS of (21) decreases with increasing tax rate $\left(\frac{\partial R H S(21)}{\partial \mu}<0\right)$. Applying the principle of diminishing returns to work, gives: $\frac{\partial \alpha^{*}{ }_{t-1}}{\partial \mu}>0$ and $\frac{\partial E\left(U^{*}{ }_{t-1}\right)}{\partial \mu}<0$. Increasing the tax rate increases the proportion of time spent on the illegal market but

${ }^{11}$ See for example Epstein, Hillman and Weiss (1999).

${ }^{12}$ Immigration policies are often expressions of preferences for cultural homogeneity. See Hillman (1994), Benhabib (1996) and Hillman and Weiss (1998). 
decreases the immigrants' expected earnings. In turn, this affects the legal immigrant's possibility of employing an illegal immigrant, since he/she is required to accumulate more human capital before being able to afford to take this step. This would reduce the number of illegal immigrants employed by the legal immigrants.

Proposition 6: Taxing legal immigrants' earnings decreases the number of illegal immigrants they employ.

\subsection{Limiting the Legal Immigrants' Time Permit}

According to proposition 2, as immigrants approach their dates of departure, they decrease their accumulated capital, and work more hours on the illegal market. Therefore, increasing the legal immigrant's time permit increases the time he/she spends working in the legal market. Increasing the time spent on the legal market leads to an increase in the number of illegal workers employed:

Proposition 7: Increasing (decreasing) the legal immigrants' time permits increases (decreases) the proportion of time they work on the legal market and increases (decreases) the number of illegal immigrants working for legal immigrants.

This proposition describes the tradeoff between the time the legal immigrant works on the illegal market and the number of illegal immigrants working there. Decreasing the number of illegal immigrants by reducing the time permit leads to less illegal workers. However, legal immigrants spend a greater proportion of their time on the illegal market. If the aim is that legal immigrants should spend a greater proportion of time on the legal market, this would, in turn, increase in the number of illegal immigrants working in the host country.

\subsection{Renewal of Permits}

Consider the effect of increasing the frequency of renewal for legal immigrants'. This would lead to uncertainty regarding their future earnings. To make such a policy credible, the authorities have to cancel some of the permits when they expire. 
Assume legal immigrants are obliged to renew their permits at the end of each period. The probability of renewal is given by $\varphi$ and is independent of all the other variables. The immigrant's expected earnings at time $t-1 \quad(0 \leq t<T)$ are given by:

$$
E\left(U^{*}{ }_{t-2}\right)=(1-P(\alpha))\left(I_{t-1}\left(\alpha^{*}{ }_{t-1}+\beta^{*}{ }_{t-1}\right)+w_{t-1}{ }^{L}+\varphi\left(k E\left(U_{t}^{*}\right)\right)-v_{t-1}\left(\beta^{*}{ }_{t-1}\right)\right)
$$

The first order-condition is satisfied if:

$$
I_{t-1}^{\prime}(\alpha)=\left[P^{\prime}(\alpha) /(1-P(\alpha))\right]\left(I_{t-1}(\alpha)+w_{t-1}{ }^{L}+\varphi\left(\frac{1}{1+r} E\left(U_{t}^{*}\right)\right)\right)
$$

RHS in (23) is smaller than in (12). Given the diminishing returns of $I($.$) , the$ time he/she spends on the illegal market would increase.

Proposition 8: Requiring legal immigrants to renew their permits regularly would increase the time they spend on the illegal market and decrease the number of illegal immigrants they employ.

Note that the probability of a permit being renewed is independent of the time spent on the illegal market. This is because legal immigrants caught working on the illegal market are sent back to their home country, regardless of the time spent on the illegal market and whether their permits are due for renewal.

\subsection{Penalties imposed on local employers}

Consider the imposition of a penalty on local employers caught employing illegal immigrants. As pointed out above, the supply of illegal immigrants is inelastic. Therefore, such a penalty would reduce the illegal immigrants' wages. It follows from equation (18) that:

Proposition 9: Imposing a penalty on local employers caught employing illegal immigrants would increase the proportion of time legal immigrants spend in the legal market, thereby decreasing the number of illegal immigrants they employ.

\subsection{Forced savings}

Consider the effect of forcing legal immigrants to save part of their earnings. The authorities would hold these savings for the immigrants until the date of their legal 
departure. For example, in Germany, immigrants pay $10 \%$ of their earnings towards their pension. If they leave Germany legally before five years have elapsed, the authorities give them these forced savings on departure. However, migrants caught and deported lose these savings. The immigrant's expected are:

$$
E\left(U_{t-1}\right)=\left(1-P\left(\alpha_{t-1}\right)\right)\left(I\left(\alpha_{t-1}\right)+(1-\eta) w_{t-1}^{L}+k E\left(U_{t}^{*}\right)\right) \quad \forall 0 \leq t<T
$$

and

$$
E\left(U_{T}\right)=\left(1-P\left(\alpha_{T}\right)\right)\left(I\left(\alpha_{T}\right)+(1-\eta) w_{T}^{L}+\sum_{i=1}^{T}\left(\eta w_{i}^{L}\right)(1+r)^{T-i}\right)
$$

where $\eta$ is the rate of forced saving per time period.

From the previous analysis we know that the proportion of time spent on the legal market decreases in the earlier periods, but increases with time. For a large $T$, the immigrants' savings increase over time, and, concomitantly, the cost of being deported also increase.

Proposition 10: If $T$ is large enough, forced savings decrease the time the legal migrants work on the illegal market and decreases the number of illegal migrants employed by them.

\section{Concluding Remarks}

Legal migrants may work in illegal jobs while, at the same time, employing illegal migrants. Illegal migrants may specialize in a certain field or profession, such as housecleaning, teaching, daycare, cooking and providing religious services, and may themselves also employ other illegal migrants. As a result, there is an evolving subeconomy, which is, for the most part illegal, the sole purpose of which is the provision of services for migrants by other migrants. Owing to their illegal status, the migrants have no choice, but to remain on the margins of the economy. The migrants do not assimilate into the local population. Rather, a parallel sub-economy is emerging.

Various public policy strategies targeted at the assimilation of migrants have been considered. Taxing the legal immigrant's earnings reduces the number of illegal migrants they can employ, thereby facilitating assimilation. Moreover, increasing the legal immigrants' time permit would increase the proportion of time they spend 
working on the legal market. On the other hand, requiring legal migrants/temporary workers to renew their permits regularly would increase the probability of assimilation. Imposing a penalty on local employers caught employing illegal migrants would increase the proportion of time spent by the legal migrant on the legal market and decrease the number of illegal migrants they employ, as well as the probability of migrant assimilation. The authorities can hold part of legal immigrants' earnings as forced savings to be paid over to them on their day of legal departure from the country for their home country. Forced savings would decrease the immigrants' illegal jobs and decrease the number of illegal migrants employed by other migrants. 


\section{References}

Becker, G. S., “A Theory of the Allocation of Time”, Economic Journal, 75 (1965): 493-517.

Benhabib, J., "On the Political Economy of Immigration", European Economic Review, 40 (1996): 1737- 1743.

Block M.K. and Heineke J.M., "A Labor Theoretical Analysis of the Criminal Choice”, American Economic Review, 65 (1975): 314-325

Borjas, G.J., "The economics of immigration", Journal of Economic Literature, 32 (1994): 1667-1717.

Carrington, W.J., Detragiache, E. and Vishwanath, T., "Migration with Endogenous Moving Costs", American Economic Review, 86 (1996) : 909-30.

Chiswick,B.R. and Miller, P.M, "Ethnic Networks and Language Proficiency among Immigrants", Journal of Population Economics, 9 (1996): 19-35.

Church, J. and King, I., "Bilingualism and Network Externalities", Canadian Journal of Economics; 26 (1983): 337-45..

Ehrlich, I. "Participation in Illegitimate Activities: A Theoretical and Empirical Investigation", Journal of Political Economy 81(1973): 521-565.

Epstein G.S., Hillman A.L. and Weiss A. "Creating Illegal Immigrants", Journal of Population Economics, 12 (1999): 3-21.

Epstein G.S., Hillman A.L. and Ursprung H.W. "The King Never Emigrates”, Review of Development Economics, 3 (1999): 107- 121.

Epstein G.S. and Hillman A.L. "Herd Effects and Migration", CEPR Discussion Paper No. 1811 (1998).

Ethier W. "Illegal Immigration: The Host Country Problem", American Economic Review, 76 (1986): 56-71.

Hillman, A.L., "The political economy of migration policy," in Migration: A Challenge for Europe, edited by Horst Siebert, J.C.B. Mohr (Paul Siebeck), Tubingen (1994).

Hillman, A.L. and Weiss A. Beyond International Factor Movements: Culture Preferences, Endogenous Policies and Migration of People, an Overview. In : de Melo J., Faini R, and Zimmermann, K.F.. (eds) Trade and Migration, Cambridge University Press, Cambridge (1998).

Marks, C., Farewell -We're Good and Gone: The Great Black Migration, Bloomington, Indian University Press (1989). 


\section{Appendix}

\section{Proof of proposition 1}

The relationship between the proportion of time spent on the illegal market in the time periods $T$ and $T-1$ and the expected earnings during those time periods is known. The rest of the analysis is a backward induction. We assume that for $n<T$, $\alpha_{n-1}^{*}<\alpha_{n}^{*}$ and $E\left(U_{n-1}^{*}\right)>E\left(U_{n}^{*}\right)$ and show that $\alpha_{n-2}^{*}<\alpha_{n-1}^{*}$ and $E\left(U_{n-2}{ }^{*}\right)>E\left(U_{n-1}{ }^{*}\right)$. The migrant's expected earnings at time $n-1$ are given by

$$
E\left(U_{n-1}\right)=(1-P(\alpha))\left(I(\alpha)+w^{L}+k E\left(U_{n}^{*}\right)\right)
$$

The first-order condition for the maximization of (1a) is given by,

$$
I^{\prime}(\alpha)=\left[P^{\prime}(\alpha) /(1-P(\alpha))\right]\left(I(\alpha)+w^{L}+k E\left(U_{n}^{*}\right)\right)
$$

Given the assumption of the induction $\alpha_{n-1}^{*}<\alpha_{n}^{*}$, the migrant's expected earnings at time $n-2$ are given by,

$$
E\left(U_{n-2}\right)=(1-P(\alpha))\left(I(\alpha)+w^{L}+k E\left(U_{n-1}{ }^{*}\right)\right)
$$

The first-order condition for the maximization of (3a) is:

$$
I^{\prime}(\alpha)=\left[P^{\prime}(\alpha) /(1-P(\alpha))\right]\left(I(\alpha)+w^{L}+k E\left(U_{n-1}{ }^{*}\right)\right)
$$

The induction assumes that $E\left(U_{n-1}{ }^{*}\right)>E\left(U_{n}^{*}\right)$. Clearly, the RHS of (4a) is greater than that in (2a). Thus, it is clear that: $\alpha_{n-2}^{*}<\alpha_{n-1}^{*}$ and $E\left(U_{n-2}^{*}\right)>E\left(U_{n-1}^{*}\right)$.

\section{Q.E.D.}

\section{Proof of proposition 2}

Time period $\boldsymbol{T}-1$ : The migrant's expected earnings at time $T-1$ is given by

$$
E\left(U_{T-1}\right)=(1-P(\alpha))\left(I(\alpha)+w^{L}+k E\left(U_{T}^{*}\right)\right)-P(\alpha) K(T-1)
$$


In determining the proportion of time they should spend on the illegal market in period $T-1$, immigrants aim to maximize their expected earnings over both periods. The first-order condition is given by:

$$
I^{\prime}(\alpha)=P^{\prime}(\alpha) /(1-P(\alpha))\left(I(\alpha)+w^{L}+k E\left(U_{T}^{*}\right)+K(T-1)\right)
$$

The relationship between the proportion of time spent on the illegal market under both options, with and without the loss of accumulated wealth, is now considered, taking into account the cost of being caught in both cases. The option with the higher cost and lower level of time spent on the illegal market is preferred. Formally, the RHSs of (6a) and (9) are compared. Given $\alpha=\alpha_{K, T}^{*}$ the RHS of (9) is given by:

$$
\operatorname{RHS}(9)=P^{\prime}\left(\alpha_{K, T}^{*}\right) /\left(1-P\left(\alpha_{K, T}^{*}\right)\right)\left(I\left(\alpha_{K, T}^{*}\right)+w^{L}+K(T)\right)
$$

and the RHS of (6a) is,

$$
R H S(6 a)=\left\lfloor P^{\prime}\left(\alpha_{K, T}^{*}\right) /\left(1-P\left(\alpha_{K, T}^{*}\right)\right)\right]\left(I\left(\alpha_{K, T}^{*}\right)+w^{L}+k E\left(U_{T}^{*}\right)+K(T-1)\right)
$$

Condition:

$$
k E\left(U_{T}^{*}\right)>K(T)-K(T-1)
$$

It is not clear whether (9a) holds or not. The LHS of (9a) is the discounted value of the future expected earnings and the RHS of (9a) is the increase in the value of the accumulated capital. (8a) is greater than (7a) if and only if $\alpha_{K, T}^{*}>\alpha_{K, T-1}^{*}$ otherwise $\alpha_{K, T}^{*}<\alpha_{K, T-1}^{*}$. We now turn to look at period $T-2$ :

$$
E\left(U_{T-2}\right)=(1-P(\alpha))\left(I(\alpha)+w^{L}+k E\left(U_{T-1}^{*}\right)\right)-P(\alpha) K(T-2)
$$

First order condition

$$
I^{\prime}(\alpha)=P^{\prime}(\alpha) /(1-P(\alpha))\left(I(\alpha)+w^{L}+k E\left(U_{T-1}{ }^{*}\right)+K(T-2)\right)
$$

Following the same calculation as in (6a), (7a) and (8a), $\alpha_{K, T-1}^{*}>\alpha_{K, T-2}^{*}$ iff

$$
k\left(E\left(U_{T-1}^{*}\right)-E\left(U_{T}^{*}\right)\right)>K(T-1)-K(T-2)
$$


Namely, this will be true only if the discounted expected earnings attributed to period $T-1$ is greater than that expected for the accumulation of wealth in the period that. In general, for $t \leq T \alpha_{K, t-1}^{*}>\alpha_{K, t-2}^{*}$ iff (the proof is by induction using the same arguments as in proposition 1)

$$
k\left(E\left(U_{t-1}^{*}\right)-E\left(U_{t}^{*}\right)\right)>K(t-1)-K(t-2)
$$

A new immigrant with low level of wealth accumulation on arrival, and thus in the initial $T_{1}$ period, there is an increase in the level of capital such that:

$$
k\left(E\left(U_{t-1}^{*}\right)-E\left(U_{t}^{*}\right)\right)<K(t-1)-K(t-2)
$$

Thus, until time $T_{1}$, the immigrant spends more and more time on the legal market. Immigrant who are approaching their departure date $T$ stop accumulating capital. Moreover, the total level may also decrease, $K(t-1)-K(t-2)<0$, as a result of preparing for departure and the return home. In this case, it is clear that for $t>T_{1}$ $k\left(E\left(U_{t-1}^{*}\right)-E\left(U_{t}^{*}\right)\right)>K(t-1)-K(t-2)$, which gives a U-shaped curve of the relationship between the proportion of time on the illegal market and the time spent in the country.

Q.E.D.

\section{Proof of lemma 1}

By assumption, $\frac{\partial v_{t}(\cdot)}{\partial t}<\frac{\partial\left(I_{t}(\cdot)+w_{t}^{L}\right)}{\partial t}$, i.e., the increase in human capital is greater for legal than for illegal immigrants. Thus, in the period after the optimal time for employing an illegal immigrant, the increase in human capital (earnings per unit of time) is greater for legal than the illegal immigrants. Therefore, the timing would be optimal for legal immigrants to employ illegal workers.

Q.E.D. 
Figure 1

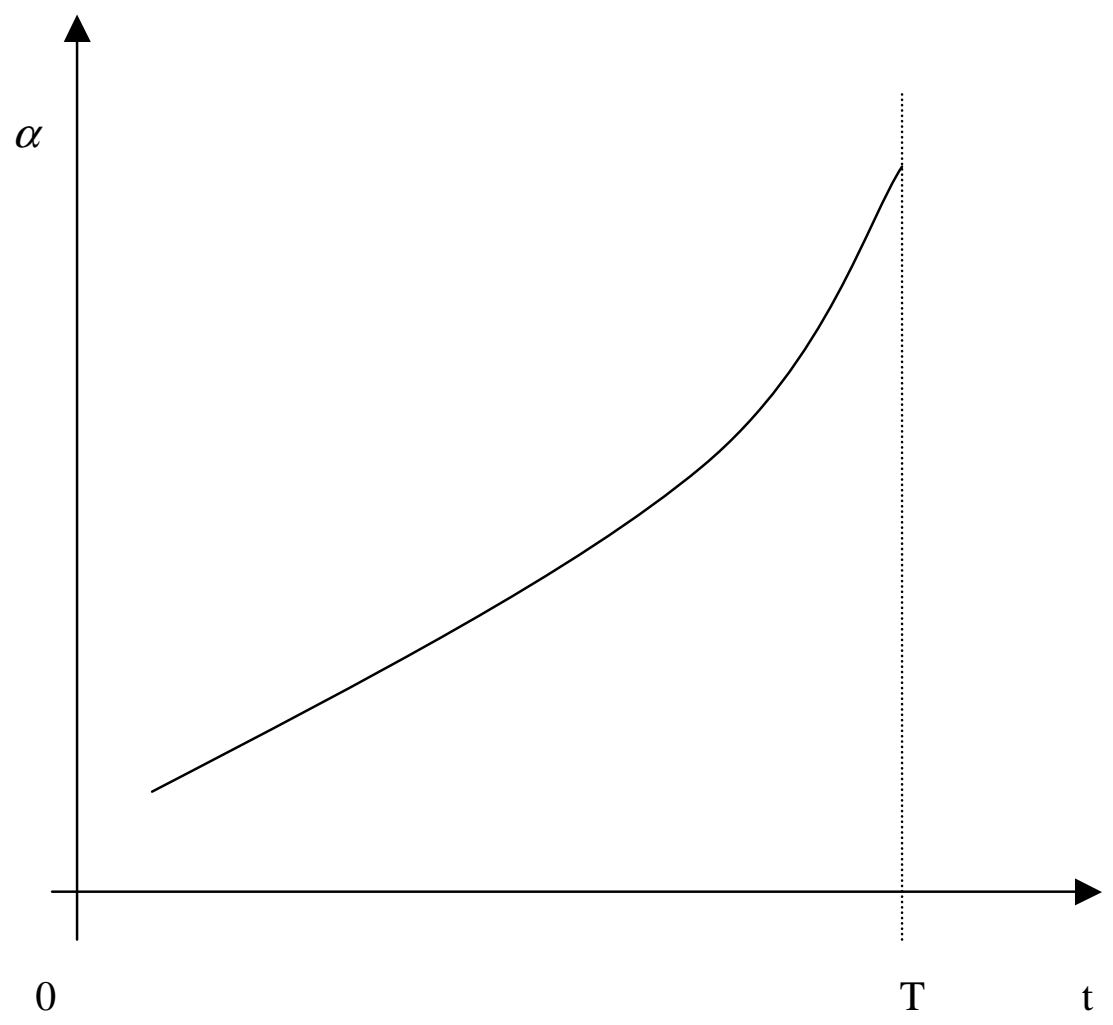

Figure 2

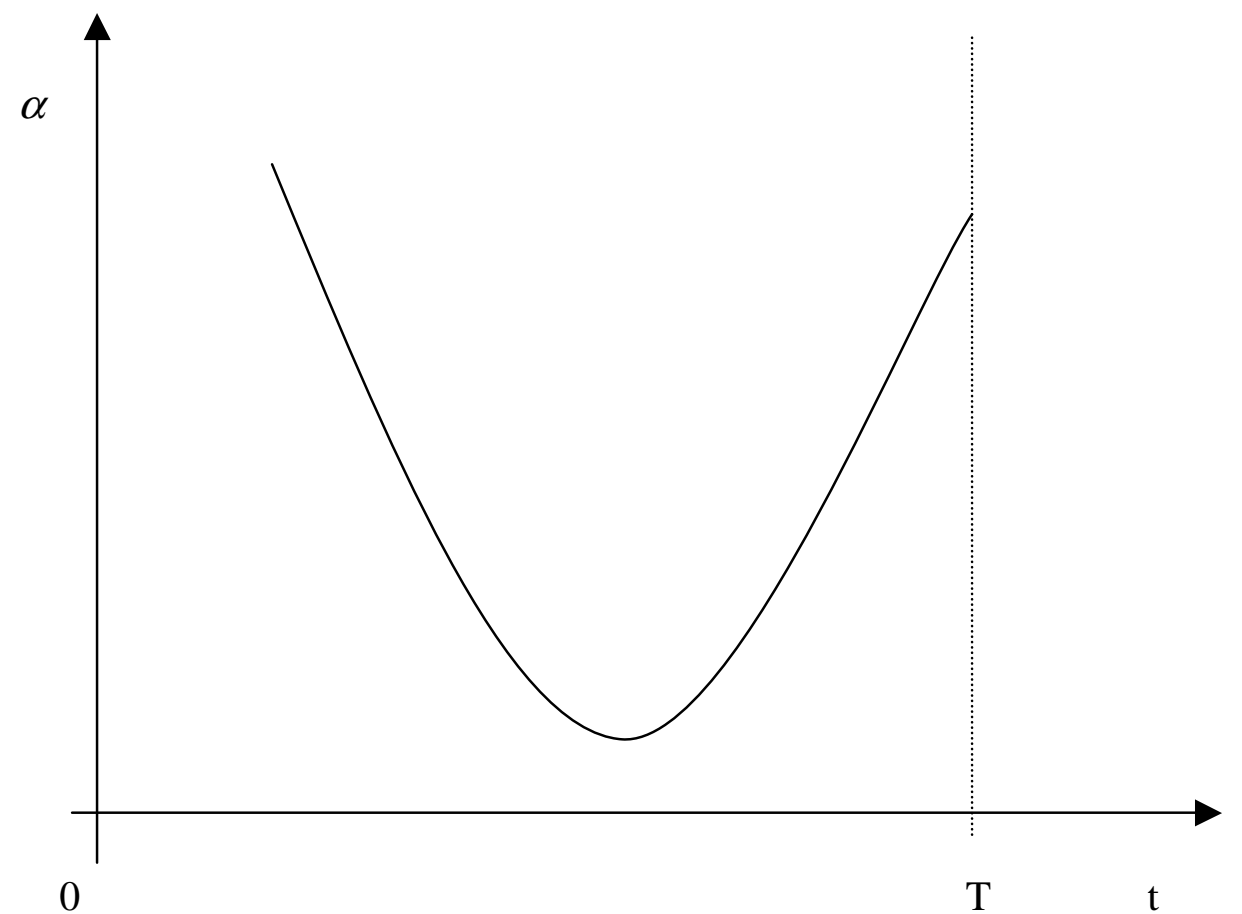




\section{IZA Discussion Papers}

\section{No Author(s) \\ 111 V. Sorm \\ K. Terrell \\ 112 L. Bellmann \\ T. Schank}

113 R. Euwals

114 G. Brunello

A. Medio

115 A. Cigno

F. C. Rosati

116 C. Belzil

117 S. Bender

A. Haas

C. Klose

118 M. A. Shields

M. E. Ward

119 A. Lindbeck

D. J. Snower

120

P. T. Pereira

P. S. Martins

121

J. C. van Ours

D. Munich

J. Svejnar

K. Terrell

123 J. Hunt

124 R. T. Riphahn

125 F. Büchel

J. R. Frick

126 J. Fersterer

R. Winter-Ebmer
Titel

Area

Date

Sectoral Restructuring and Labor Mobility:

A Comparative Look at the Czech Republic

$1 / 4$

$2 / 00$

Innovations, Wages and Demand for

5

$2 / 00$

Heterogeneous Labour: New Evidence from a

Matched Employer-Employee Data-Set

Do Mandatory Pensions Decrease Household

Savings? Evidence for the Netherlands

3

$2 / 00$

An Explanation of International Differences in

2

$2 / 00$

Education and Workplace Training

Why do Indian Children Work, and is it Bad for

3

$2 / 00$

Them?

Unemployment Insurance and Subsequent Job

3

$2 / 00$

Duration: Job Matching vs. Unobserved

Heterogeneity

IAB Employment Subsample 1975-1995.

Opportunities for Analysis Provided by the

Anonymised Subsample

Improving Nurse Retention in the British National

5

$2 / 00$

Health Service: The Impact of Job Satisfaction on Intentions to Quit

The Division of Labor and the Market for

Organizations

5

$2 / 00$

Does Education Reduce Wage Inequality?

Quantile Regressions Evidence from Fifteen

European Countries

5

$2 / 00$

Do Active Labor Market Policies Help Unemployed $\quad 4 / 6$

$3 / 00$

Workers to Find and Keep Regular Jobs?

Returns to Human Capital under the Communist

4

$3 / 00$

Wage Grid and During the Transition to a Market

Economy

Why Do People Still Live in East Germany? 1

$3 / 00$

Rational Poverty or Poor Rationality? The Take-up 3

$3 / 00$

of Social Assistance Benefits

The Income Portfolio of Immigrants in Germany -

Effects of Ethnic Origin and Assimilation. Or:

Who Gains from Income Re-Distribution?

Smoking, Discount Rates, and Returns to

5 
The Employment, Unemployment and

Unemployment Compensation Benefits of Immigrants

Is There a Wage Premium for Returning Irish

Migrants?

Unemployment and Productivity Growth: An

Empirical Analysis within the Augmented Solow Model

138 J. Zweimüller R. Winter-Ebmer

Continuous Training in Germany

Firm-specific Training: Consequences for Job

$3 / 00$ Mobility

139 R. A. Hart

Wages, Hours and Human Capital over the

$3 / 00$ Y. Ma

Life Cycle

140 G. Brunello

S. Comi

Education and Earnings Growth: Evidence from 11 European Countries

The Effects of Public Sector Sponsored Training on Individual Employment Performance in East Germany 
148 L. Goerke

149 R. Lalive J. C. van Ours J. Zweimüller J.-St. Pischke

151 M. Ward

152 J. J. Dolado

F. Felgueroso

J. F. Jimeno

153 A. S. Kalwij

M. Gregory

154 M. Gerfin

M. Lechner

155 J. Hansen

156 C. Dustmann

F. Fabbri

157 P. Apps

R. Rees

158 A. Björklund

T. Eriksson

M. Jäntti

O. Raaum

E. Österbacka

159 P.- J. Jost

M. Kräkel

160

M. Lofstrom

D. Treisman

G. Monusova
Does the Recent Success of Some OECD Countries in Lowering their Unemployment Rates Lie in the Clever Design of their Labour Market Reforms?

Employment Effects of Labour Taxation in an Efficiency Wage Model with Alternative Budget Constraints and Time Horizons

The Impact of Active Labor Market Programs and Benefit Entitlement Rules on the Duration of Unemployment

Unions and the Labor Market for Managers

3 $4 / 00$

Gender, Salary and Promotion in the Academic Profession

The Role of the Minimum Wage in the Welfare State: An Appraisal 1975-1999: A Panel Data Analysis

Microeconometric Evaluation of the Active Labour 6 Market Policy in Switzerland

The Duration of Immigrants' Unemployment Spells: $\quad 1 / 3$

Evidence from Sweden

$5 / 00$

Language Proficiency and Labour Market Per- 1 formance of Immigrants in the UK

$5 / 00$

Household Production, Full Consumption and $\quad 7$ the Costs of Children

Brother Correlations in Earnings in Denmark, 5 $5 / 00$ Finland, Norway and Sweden Compared to the United States

A Comparison of the Human Capital and Signaling Models: The Case of the Self-Employed and the Increase in the Schooling Premium in the 1980's

Public Employment and Redistributive Politics: 4 $6 / 00$

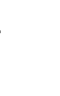


Barrachina

The Impact of Alcohol Consumption on Occupa- 5 tional Attainment in England

B. Nolan

Immigration into Ireland

168 G. S. Epstein

Social Harmony at the Boundaries of the Welfare 3

A. L. Hillman

State: Immigrants and Social Transfers

169 R. Winkelmann

Immigration Policies and their Impact: The Case of 1 New Zealand and Australia

Wages and the Demand for Health - A Life Cycle

between Skilled and Unskilled Blue-Collar Workers within Establishments: An Empirical Analysis with Data of Manufacturing Firms 
Joint Decisions on Household Membership and Human Capital Accumulation of Youths: The role of expected earnings and local markets

192 G. Brunello

193 A. Kunze

Absolute Risk Aversion and the Returns to 
198 M. Kreyenfeld

C. K. Spiess

G. G. Wagner

199 H. Entorf

200

T. Bauer

G. S. Epstein

I. N. Gang

201 T. J. Dohmen

G. A. Pfann

202

P. Francois

J. C. van Ours

203 J. M. Abowd

F. Kramarz

D. N. Margolis

T. Philippon

204 G. S. Epstein
A Forgotten Issue: Distributional Effects of Day

3

$9 / 00$

Care Subsidies in Germany

Rational Migration Policy Should Tolerate Non-

1

$9 / 00$

Zero Illegal Migration Flows: Lessons from

Modelling the Market for Illegal Migration

What are Migration Networks?

$9 / 00$

Worker Separations in a Nonstationary Corporate 1

$9 / 00$

Environment

Gender Wage Differentials in a Competitive Labor

5

Market: The Household Interaction Effect

$9 / 00$

The Tail of Two Countries: Minimum Wages and 5

$9 / 00$

Employment in France and the United States

Labor Market Interactions Between Legal and

1

$10 / 00$

Illegal Immigrants 